\title{
MODELLING METHODS FOR SOIL-STRUCTURE INTERACTION APPLIED IN WIND TURBINE FOUNDATION DESIGN
}

\author{
George CATANĂ - PhD Student, Technical University of Civil Engineering, Faculty of Civil Engineering, \\ e-mail: george.catana@yahoo.com
}

Adrian - Alexandru SAVU - Assist. Prof., PhD, Technical University of Civil Engineering, Faculty of Civil Engineering, e-mail: adrian.alex.savu@gmail.com

Ionuț EALANGI - PhD Student, Technical University of Civil Engineering, Faculty of Civil Engineering, e-mail: ealangiionut@yahoo.com

\begin{abstract}
The article presents a case study on soil-structure interaction modelling for Wind turbines. After a brief presentation on the history of wind turbines and their potential in Romania, the authors take on the task of modelling the soil-structure interaction for the raft and piles. Three models are chosen: in the first model the piles are fixed at foundation depth; in the second, elastic supports are modelled on the raft and the piles and in the third model both elastic supports and fixed supports are modelled. Several comparisons are made between the three cases referring to displacements, efforts and necessary reinforcement. Based on these comparisons, the most important conclusion drawn is that the modelling of the soil-structure interaction has an important effect on the final reinforcement of the raft and the piles, considering that the difference between the models reaches almost $18 \%$, which in the case of really large foundations can draw the line between economic and non-economic design.
\end{abstract}

Keywords: tower, cost, raft, pile, Winkler model

\section{Introduction}

The expression 'harvest wind energy' symbolizes, mainly, the nonpolluting electric energy produced at a large scale by the modern 'wind mills' coined 'wind turbines'. By using this name the similarity with steam or gas turbines, used to produce electric current and also to make a clear distinction between the old and the new use is accentuated [1]. The functioning of a wind turbine is based on a simple principle. The wind causes the movement of the blades, which in turn actuate the electric generator. The mechanical system include also a gearbox that actuate the main shaft of the generator [2].

\section{Brief history of wind energy}

Five thousand year old documents show that sail was used on the Nile river. First wind mills were probably with a vertical shaft, due to its simplicity. Turbines like the one in Fig. 1 a) were used in Persia around 200 B.C. to pump water or grind wheat. Later wind mills with horizontal shaft were invented, comprising up to ten wood blades with cloth. In the 10th and 11th century the wind mills were used on a large scale in the Middle East. In Europe the wind mills appeared in the 11th and 12th century and apparently were introduced on two ways, by the Moors in Spain and by the crusaders who returned from the East respectively. In the 14th century the Dutch opened the way for the improvement of the wind mills, using them on a massive scale to drain the swamps and lakes in the Rhine Delta (Fig. 1 b)) $[3,4]$. In U.S.A. over 6.5 million wind mills of various power were in operation starting in the mid-11th century and continuing until 1930 (Fig. $1 \mathrm{c}))$ [3].

The first evidence of using wind energy in Romania dates back to 1385 A.D. in the Dobrogea region. Significant usage was recorded in Moldova (in the South and on the Prut river meadow). A large number of wind mills were used in the Oltenia and Banat regions also. 


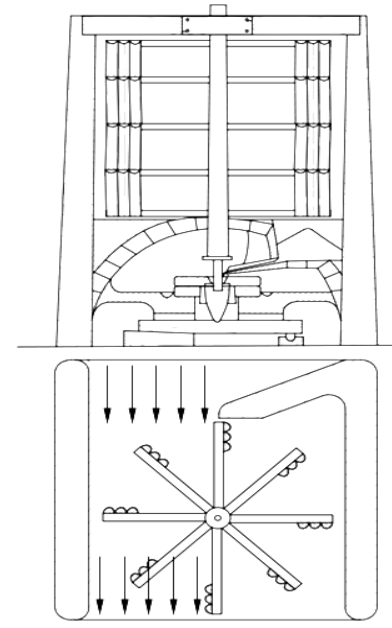

a)

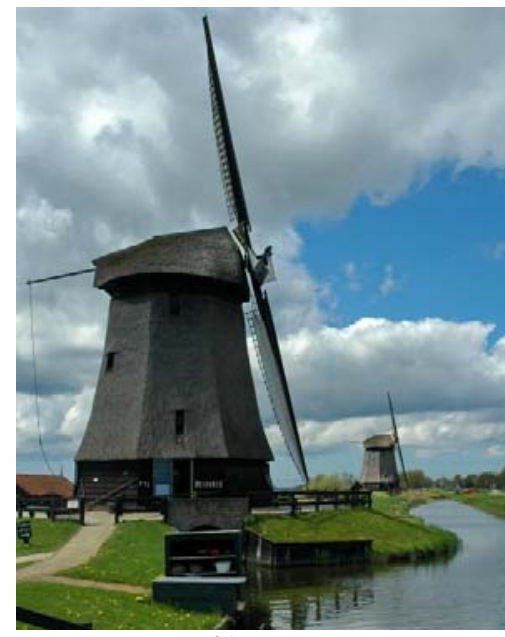

b)

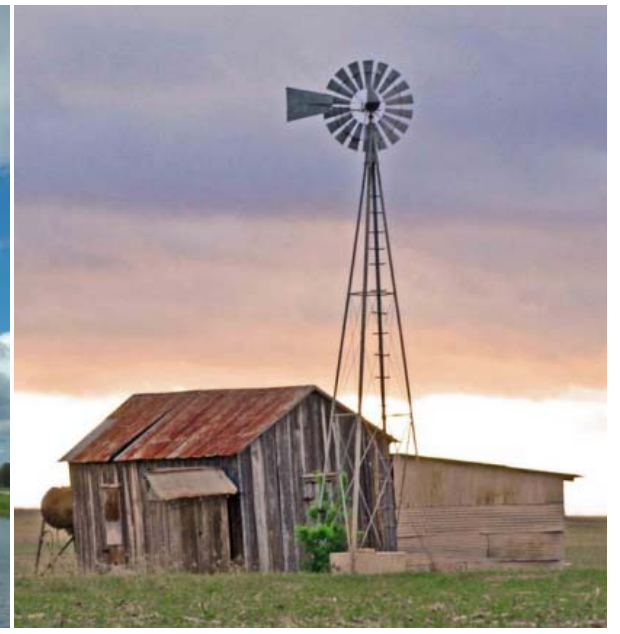

c)

Fig. 1 - a) Wind mill with vertical shaft [1], b) Dutch wind mill, c) farm wind mill

The discovery of electricity, the development of generators and electric batteries provided an additional market for the wind mills with the aim of producing this new type of energy. So, the first attempts to produce electric power from the wind go back over a hundred years, starting with the end of the 19th century [3].

If in 1973 the main stimulus for the development of wind energy conversion systems was the price of oil, today a second one emerged: the tendency to produce 'clean' or 'green' electric energy without or with small carbon oxide emission [1]. In Fig. 2 the global cumulative installed wind capacity is represented for the past 16 years [5].

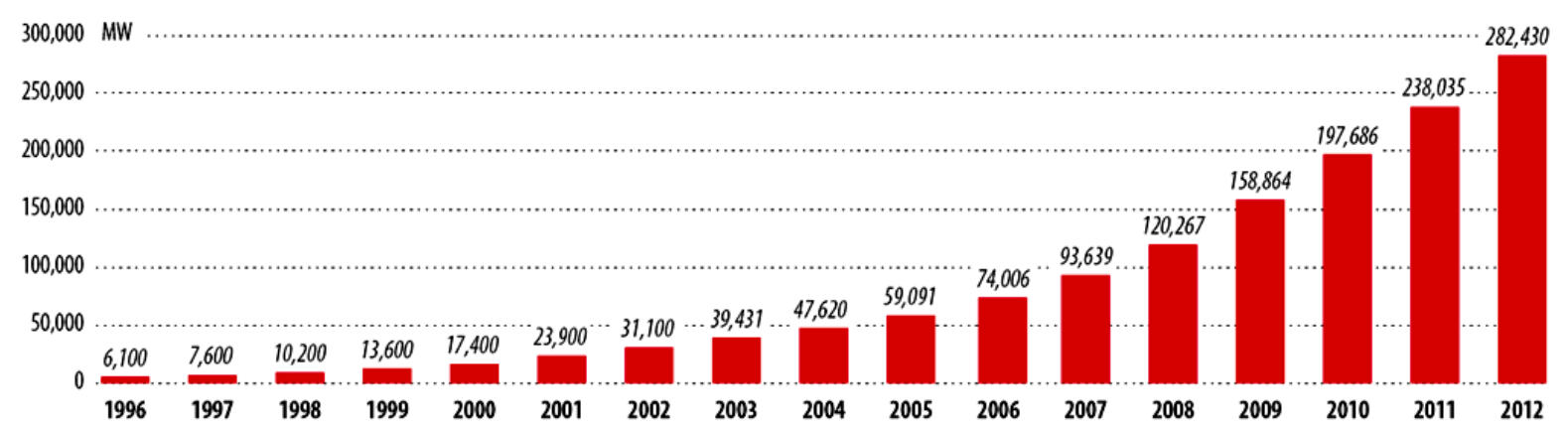

Fig. 2 - Global cumulative installed wind capacity, 1996-2012 [5]

The continuous annual growth of the globally installed capacity can be observed, growth promoted in the last 10 years by the technological development and the renewable energy laws that encourages investments in this sector. Thus, one can notice that the total installed power in 2012 increased approximately 9 times the value from 2002.

The global tendency manifested in Romania during the last 4 years, reaching in 2012 the amount of $1905 \mathrm{MW}$ of installed power, compared to $8 \mathrm{MW}$ in 2008 [6]. The reasons for this increase are the EU Directive regarding renewable energy resources, the high wind potential across the country and the investor friendly laws [5].

\section{The main components of a wind turbine}

The major components of a wind turbine are the following (Fig. 3 a)) [2]:

- Blades - their design is essential to provide the necessary rotational force. There is a specific design for each type of generator,

- Nacelle - contains and protects the electric generator, 
- Tower - provide the support and stability for the superstructure,

- Foundation (Footing) - ensures the mechanical integrity of the ensemble.

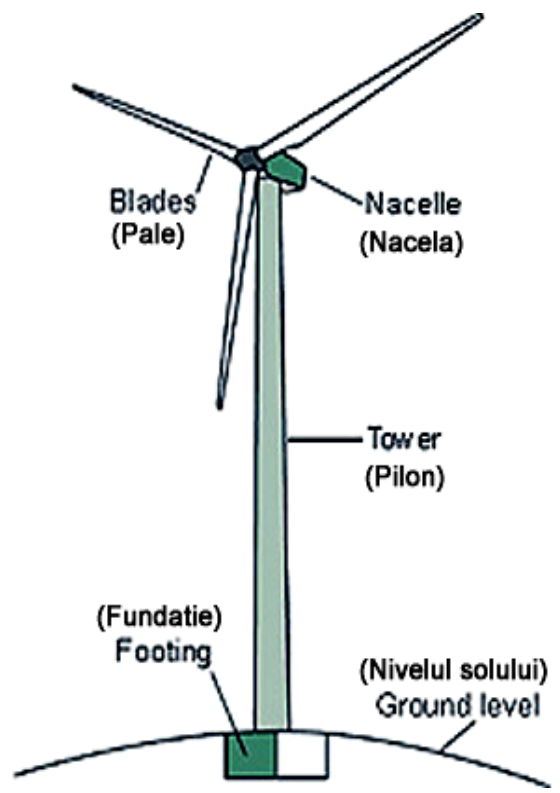

a)

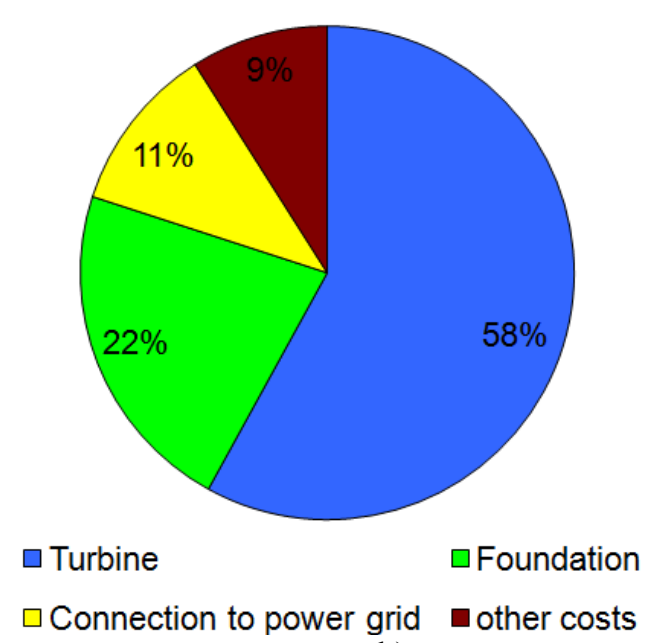

b)

Fig. 3 - a) Components of a wind turbine with horizontal shaft [2],

b) the investment costs of continental wind turbines [8]

The role of the foundation is to maintain the stability and position of the turbine under extreme conditions. The design of wind turbine foundations is largely driven by the tower base overturning moment under extreme wind conditions. A variety of slab, multi-pile and monopile solutions have been adopted for tubular towers (Fig. 4) [7].

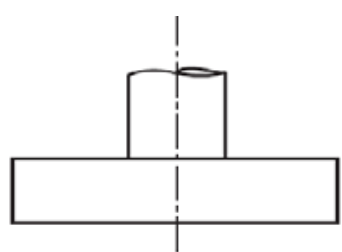

a)

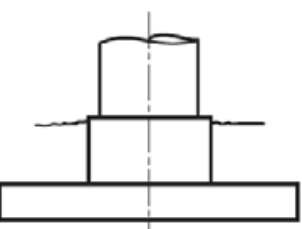

b)

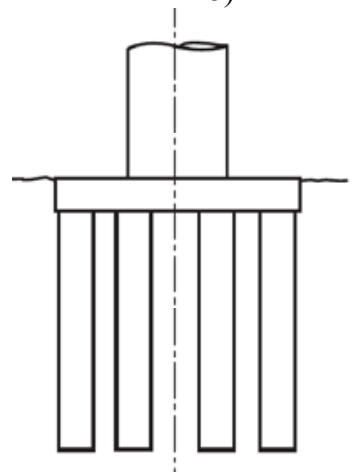

e)

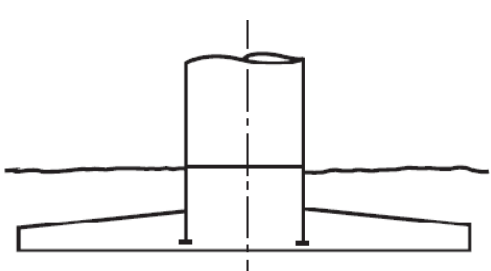

c)

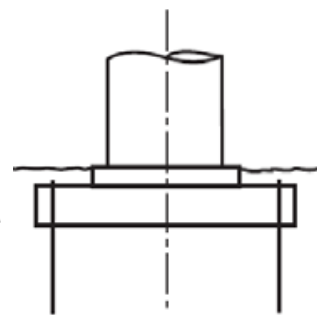

d)

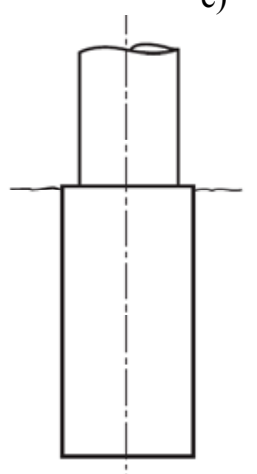

f)

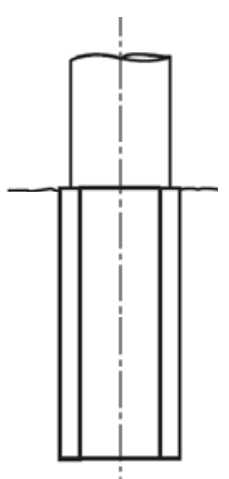

g)

Fig. 4 - Wind turbine foundations: a) plain slab, b) slab and pedestal, c) stub tower embedded in tapered slab, d) slab held down by rock anchors, d) pile group and cap, e) solid monopole, f) hollow monopole [7]

The investment costs form an important part in the determination of the efficiency of wind energy projects. This includes the costs for the turbine and for all utilities that are required for the planning, authorization, design and start-up. The design and construction costs of the foundation is about $22 \%$ from the total cost (Fig. 3 b)) [8]. 


\section{Case study}

\subsection{Presentation of the structure}

The case study's purpose is the foundation design for a wind turbine by means of three methods of modelling the soil - structure interaction. The turbine is part of a wind farm of 50 turbines located in Vânători village, Iaşi county, that, when finished, will produce a total of 95MW. The general data and the technical specifications were provided by the manufacturer (Fig. 5).

The building site has the following characteristics:

- wind exposure area, according to CR 1-1-4/2012 "Cod de proiectare. Evaluarea acţiunii vântului asupra construcţiilor", the reference wind pressure on the site, determined from the mean reference velocity in $10 \mathrm{~min}$. and having a mean recurrence interval $\mathrm{MRI}=50$ $\mathrm{yrs}$ is $\mathrm{q}_{\mathrm{ref}}=0.7 \mathrm{kN} / \mathrm{m}^{2}$;

- snow load area, according to CR 1-1-3/2012 "Cod de proiectare. Evaluarea acţiunii zăpezii asupra construcţiilor", the characteristic value for the snow load at ground level having a $2 \%$ probability of being exceeded in one year is $\mathrm{s}_{0, \mathrm{k}}=2.5 \mathrm{kN} / \mathrm{m}^{2}$;

- seismic exposure area, according to P100-1/2006 "Cod de proiectare seismică - Partea I Prevederi de proiectare pentru clădiri", the site falls into the area characterized by a peak ground acceleration of $\mathrm{a}_{\mathrm{g}}=0.20 \mathrm{~g}$ (for a mean recurrence interval MRI $=100 \mathrm{yrs}$ ), the control period $\mathrm{T}_{\mathrm{C}}=0.7 \mathrm{~s}$ and the $\mathrm{I}^{\mathrm{st}}$ importance class.

In order to follow the load transmission on the foundation it is mandatory to synthesize the types of loads that the environment applies to the structure:

- the weight of the structure determines a permanent load (constant), its share being small in the structure-foundation ensemble;

- the action of hoar-frost deposit determines a quasi-permanent load, but again their its share is small. If the hoar-frost deposit is non-uniform then the rotor of the turbine can be imbalanced, and periodical dynamic loads appear.

- the action of the wind determines random variable loads, practically continuous in time, introducing intense fatigue in the structure (the share is large with extreme values). The wind action is dependent of the electric power produced and the influence of the rotor on the tower.

- the seismic load determines short term loads with a large mean recurrence interval that can be assimilated with an isolated impulse (the share being large). Although the seismic load has a different nature than the wind load, it presents similar effects that can be sumed up as a horizontal load.

- the breakdown action (damaged rotor blade) introduces violent loads by unbalancing the rotor.

All these actions transmit special efforts towards the foundation and the foundation soil having, for the most part, predictable intensities.

At the foundation level, in the least favorable case, the following efforts are determined: axial force $-4675 \mathrm{kN}$, shear force $-1732 \mathrm{kN}$ and bending moment $-151720 \mathrm{kNm}$. 

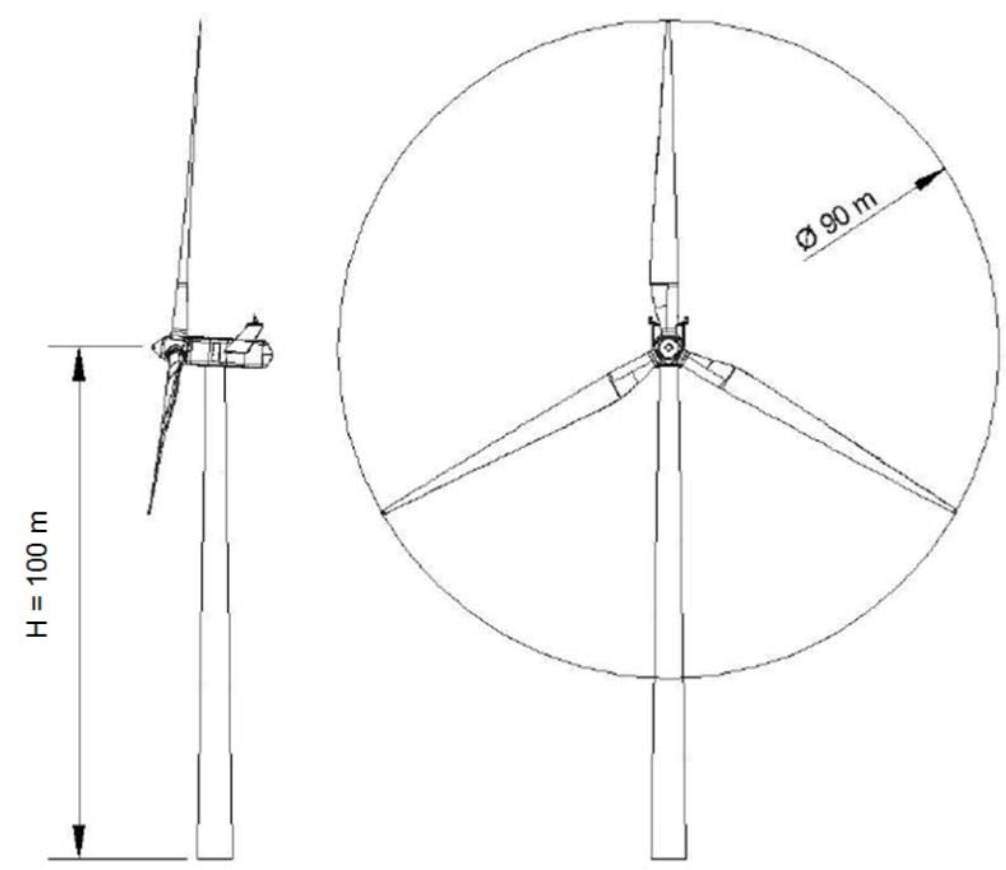

Fig. 5 - Dimensions of the turbine

\subsection{Design model}

Graitec Advance Design was used for the design of the foundation. Due to the large loads and the weak foundation soil, the foundation will be made of reinforced concrete, consisting of a circular raft with piles on the circumference. In order to study the soil-foundation system interaction the following design models were used:

- in the first case, the raft was considered supported on the piles having a fixed support at a depth of $14 \mathrm{~m}(11.50 \mathrm{~m}-$ piles $+2.50 \mathrm{~m}$ thickness of the raft $)-($ Fig. $7 \mathrm{a}))$; this is a theoretical model that does not consider the soil-pile interaction (which could be the case for a wind turbine built on several layers of weak landfill), also, from personal experience it was observed that some structural engineers used this type of model in designing wind turbines;

- in the second one, elastic supports (Winkler) were modelled on the bottom of the raft and on the sides and tip of the piles - (Fig. 7 b)); the lateral reaction model for the piles is in accordance with the current norms of the design (NP 123/2008 - "Normativ privind proiectarea geotehnică a fundaţiilor pe piloţi");

- the third case is a combination of the two models above, using fixed supports on the tip of the piles, as well as elastic supports on the bottom of the raft and on the sides of the piles - (Fig. $7 \mathrm{c})$ ).

The second and third model were selected to take into account two hypotheses regarding the embedding layer vertical support behavior: elastic $\left(2^{\text {nd }}\right.$ model $)$ vs rigid ( $3^{\text {rd }}$ model).

The values for the subgrade reaction coefficient for the piles were computed with respect to the lithological column for the site (Fig. 6 a)), using the design code values (NP 123/2008, Annex C) in relation to the consistency index of the soil layers. The design program does not support a linear variable subgrade reaction coefficient, so, instead, the coefficient was modelled as an equivalent uniform variable (Fig. 6 b)).

The meshing of the raft was created by the software, the elements being rectangles and triangles with a maximum length of each side of $0.5 \mathrm{~m}$. 


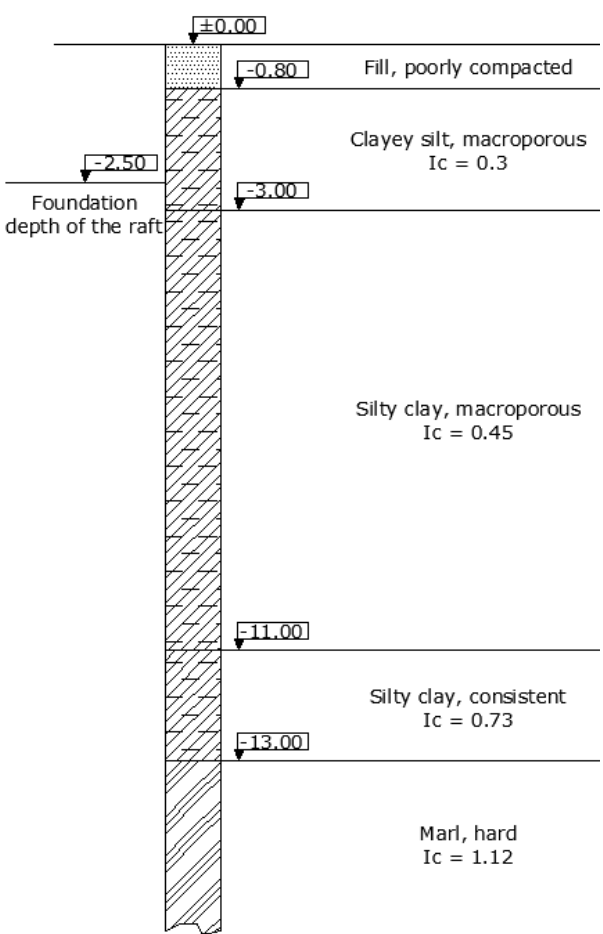

a)

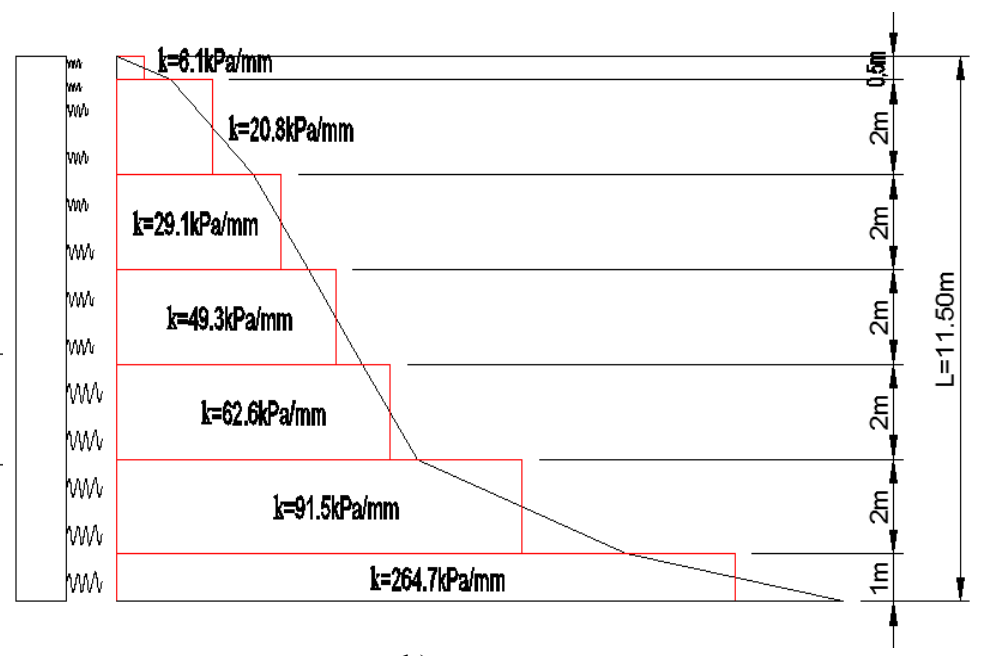

b)

Fig. 6 - a) Site lithology, b) Subgrade reaction modeling
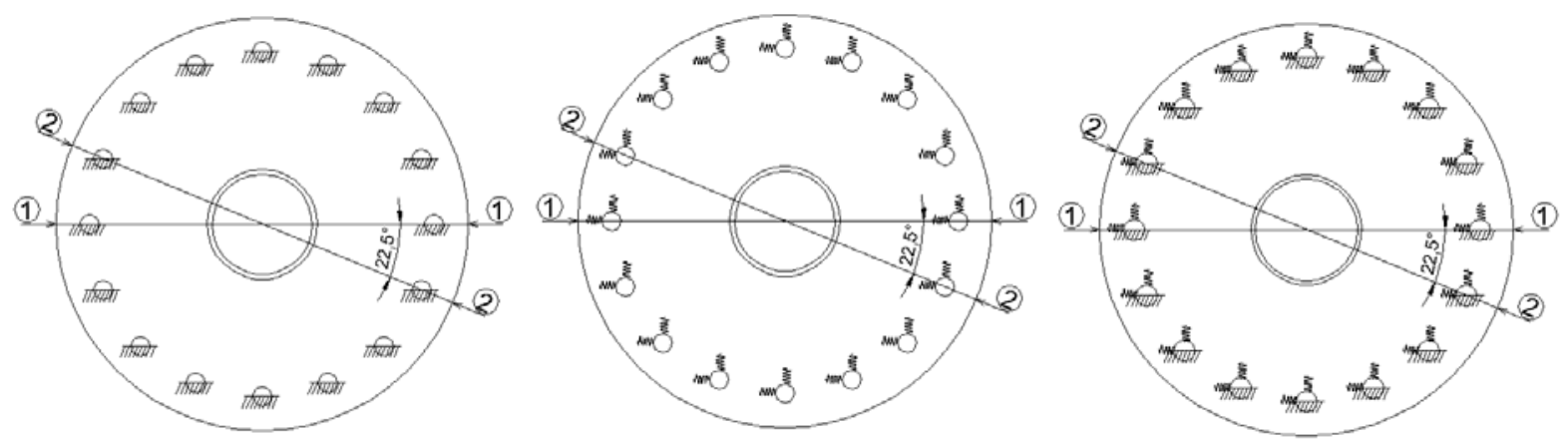

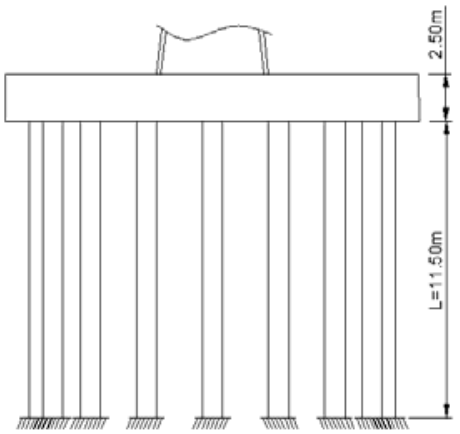

a)

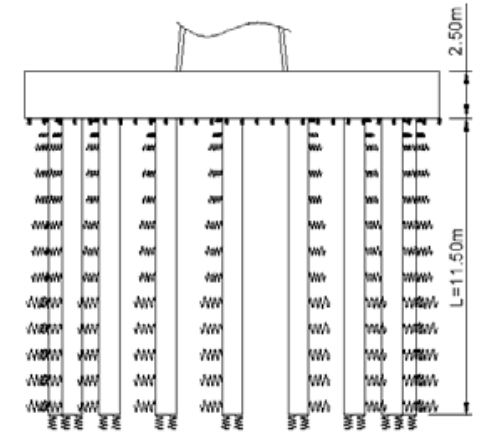

b)

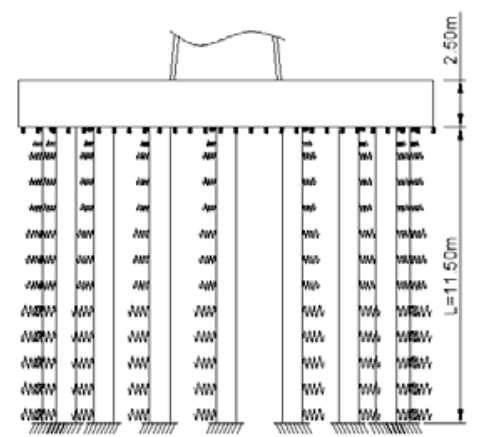

c)

Fig. 7 - a) Case I - Model with fixed piles, b) Case II - Winkler media model, c) Case III - Combined model

\subsection{Results}

In the following pages the eloquent results were extracted from the design software, in terms of displacement (settlements), axial and shear forces, bending moments, as well as necessary areas of reinforcement for the raft and the piles. 


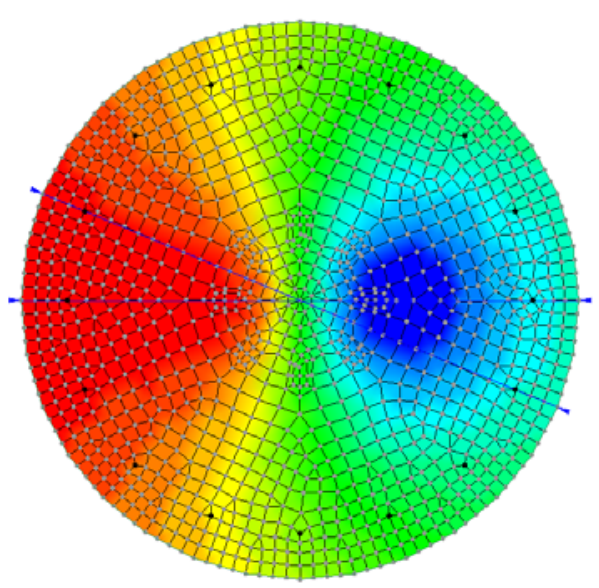

a)

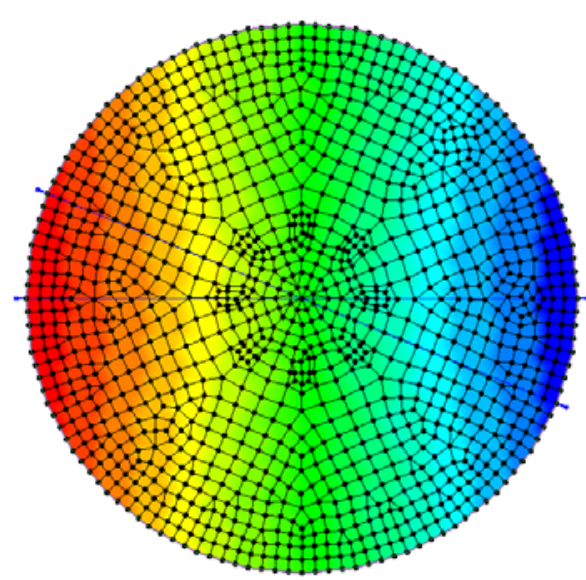

b)

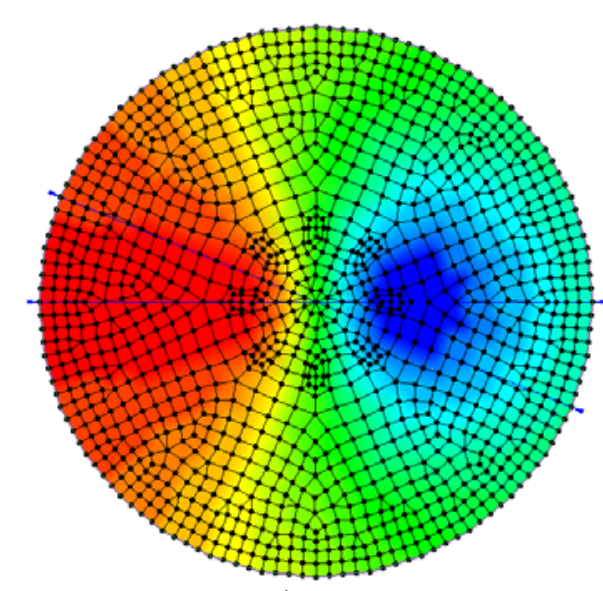

c)
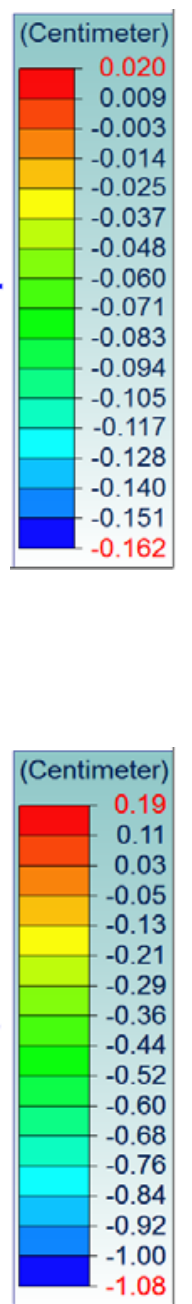

.08
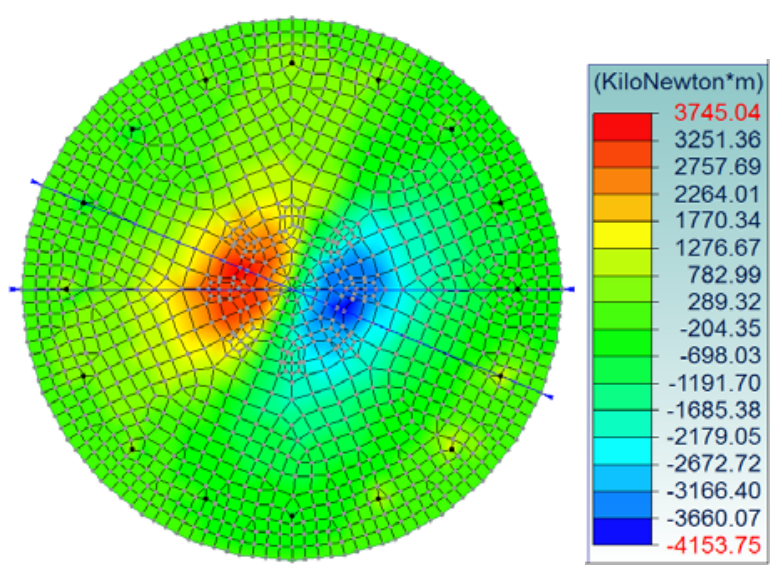

d)
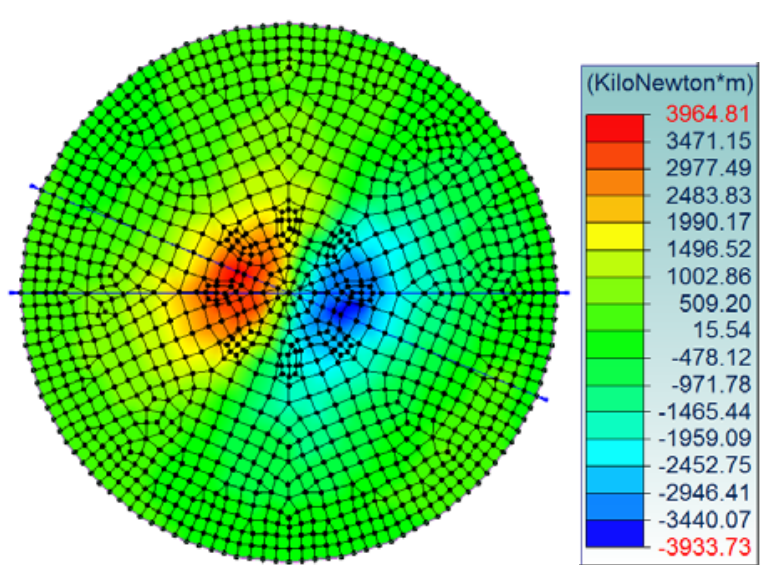

e)
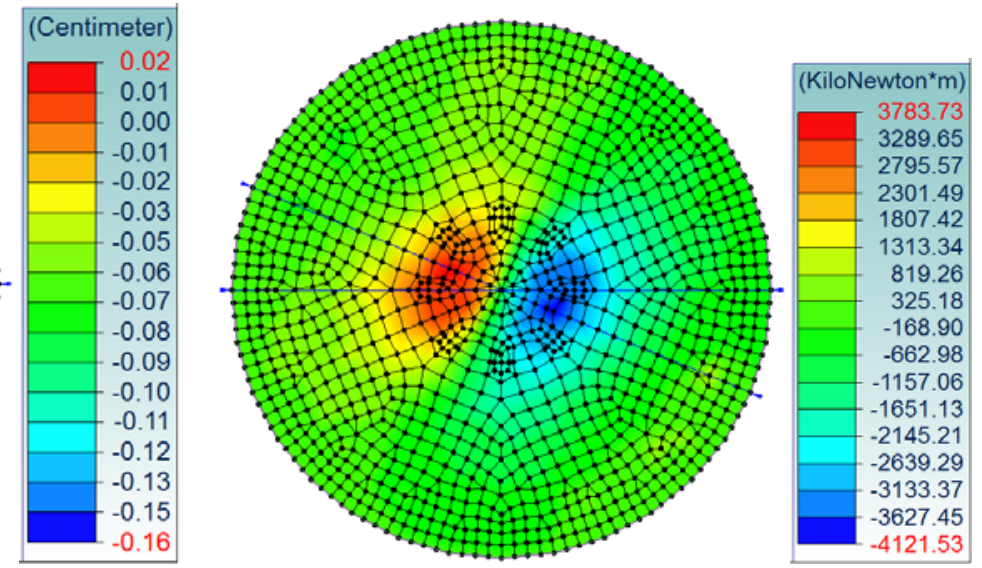

f)

Fig. 8 - Raft settlement

a) Case I, b) Case II, c) Case III

Fig. 9 - Bending moment with respect to $x$

d) Case I, e) Case II, f) Case III 


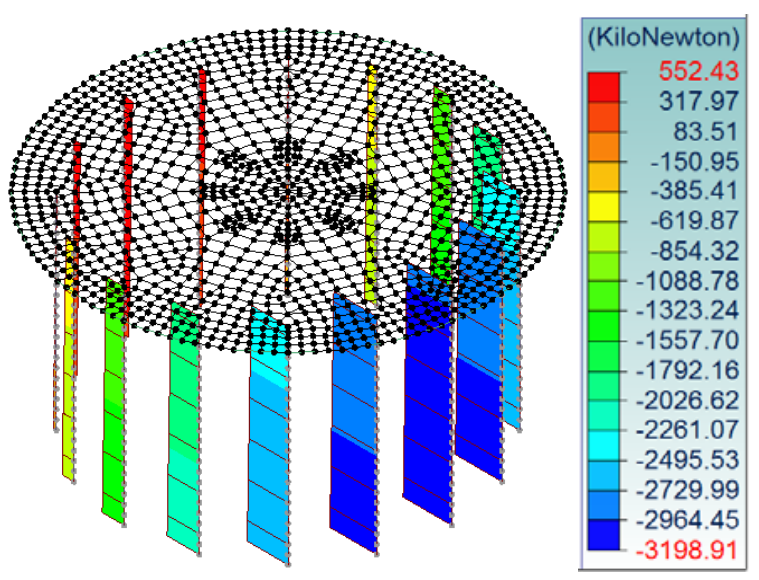

a)

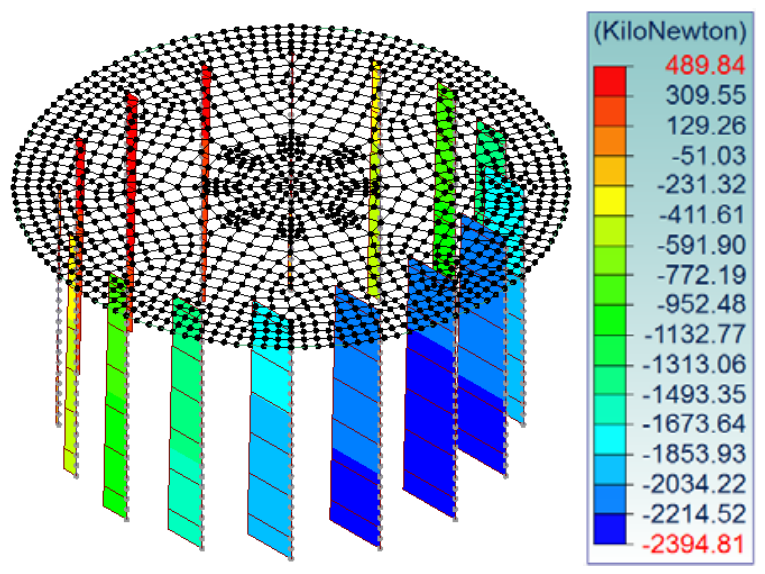

b)

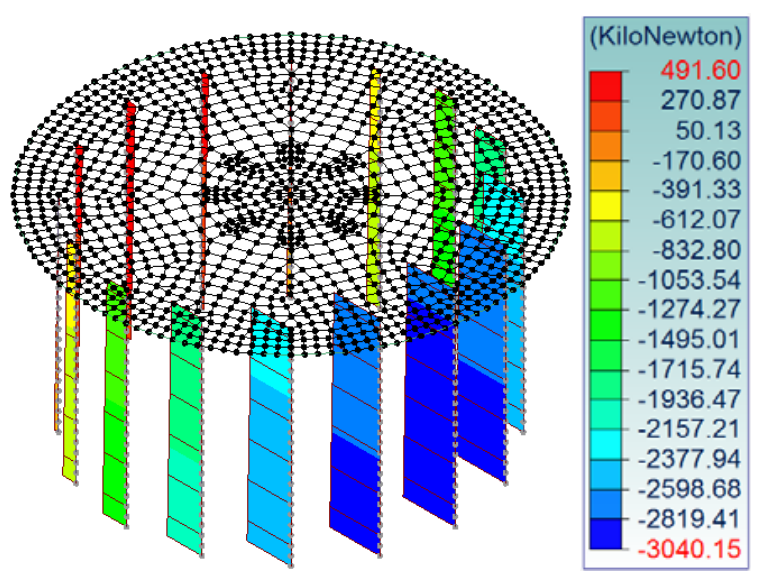

c)

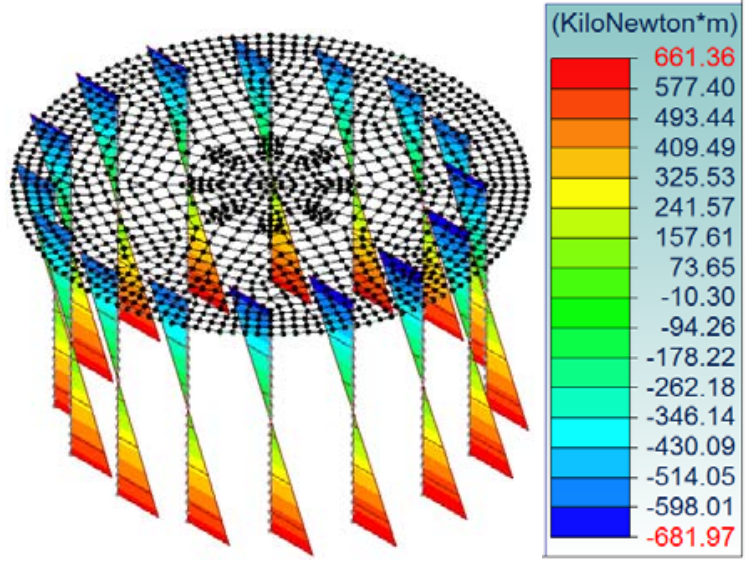

d)

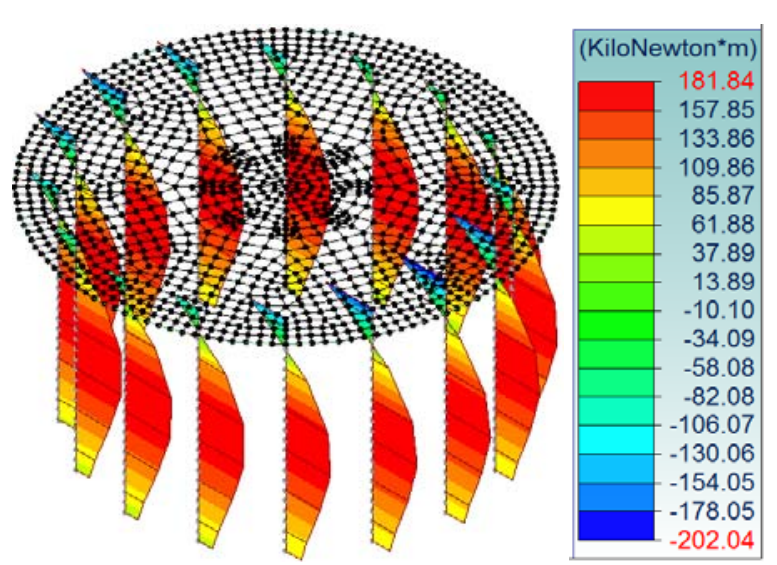

e)

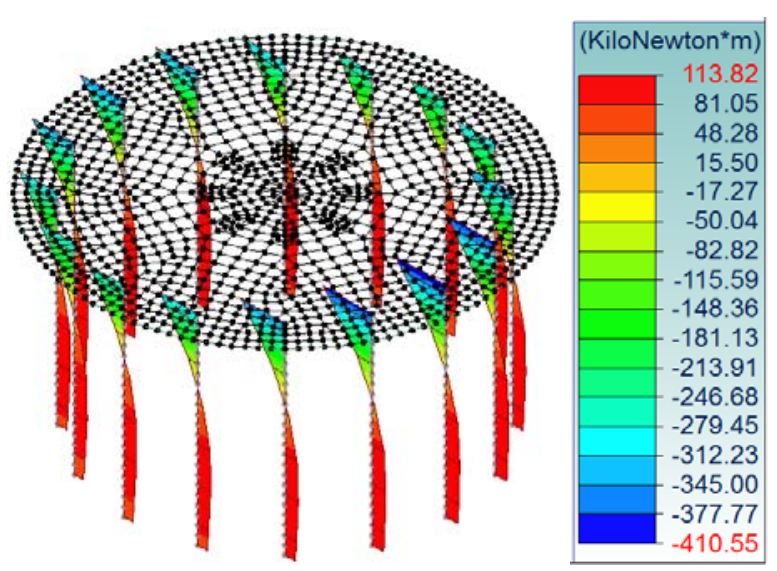

f)
Fig. 10 - Axial force in the piles

a) Case I, b) Case II, c) Case III
Fig. 11 - Bending moment in the piles

d) Case I, e) Case II, f) Case III 


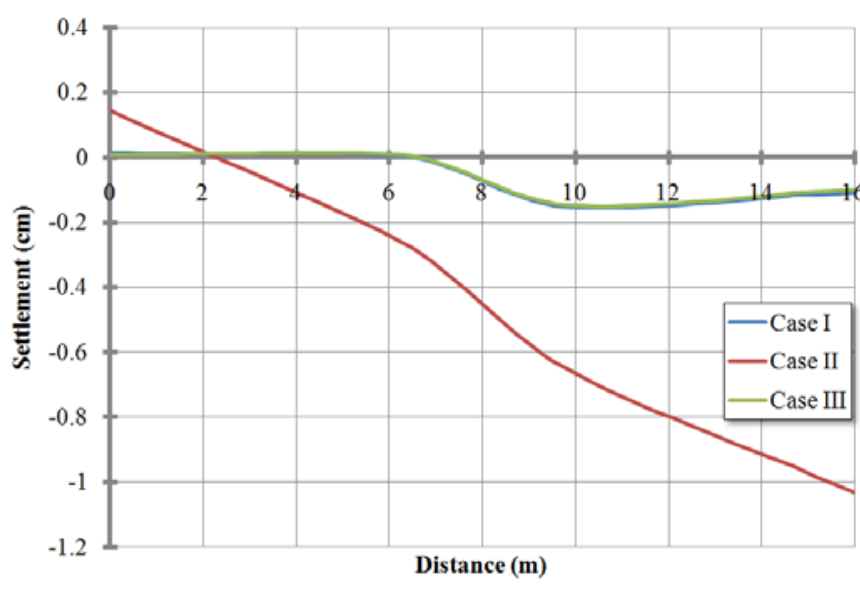

a)

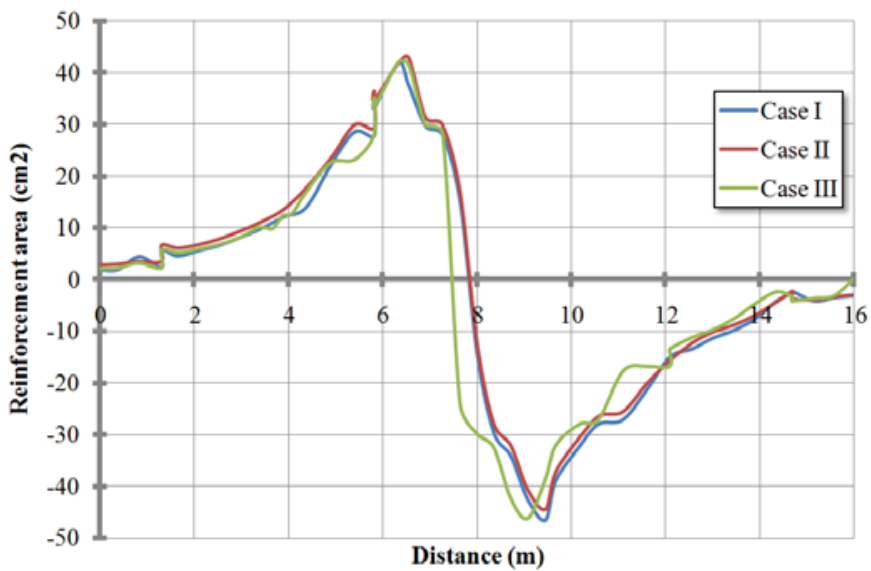

b)

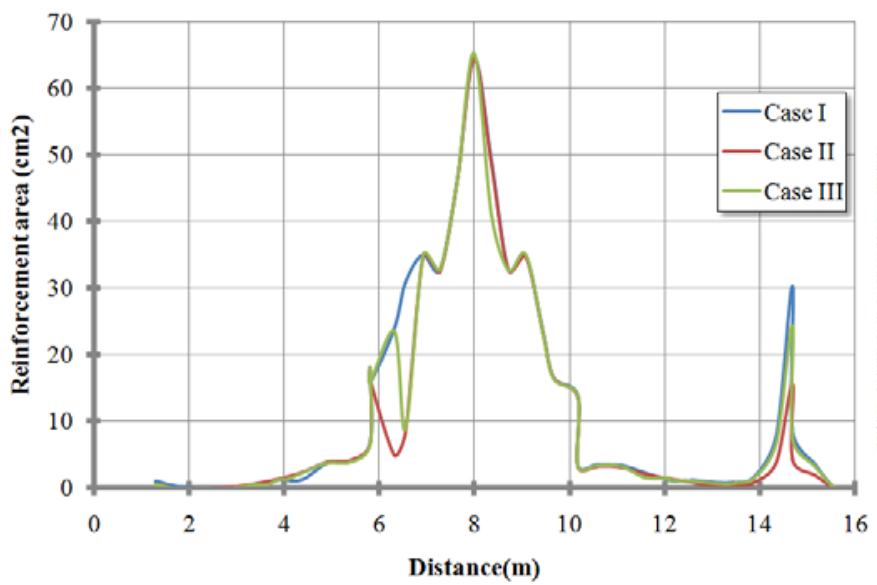

c)

Fig. 12 - Comparisons

a) raft settlement

b) necessary longitudinal reinforcement areas

c) necessary shear reinforcement areas

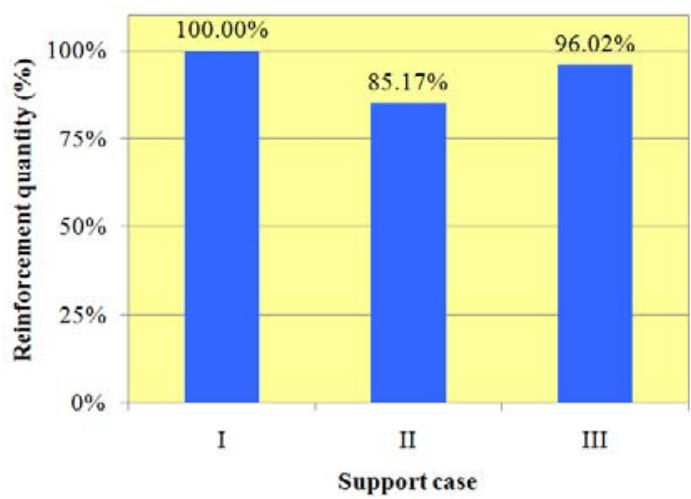

d)

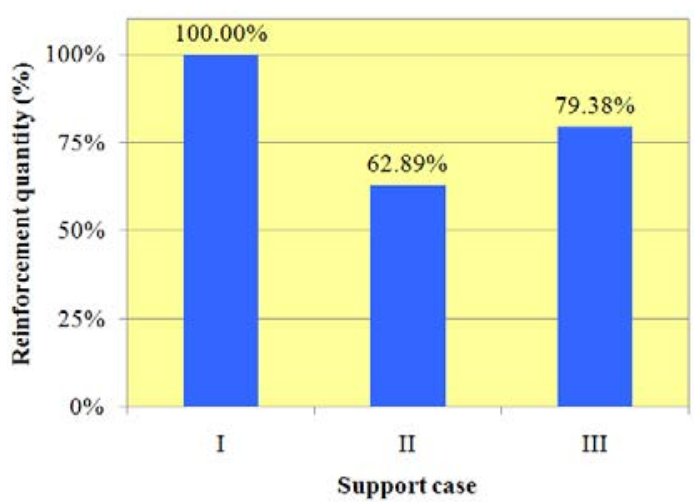

e)

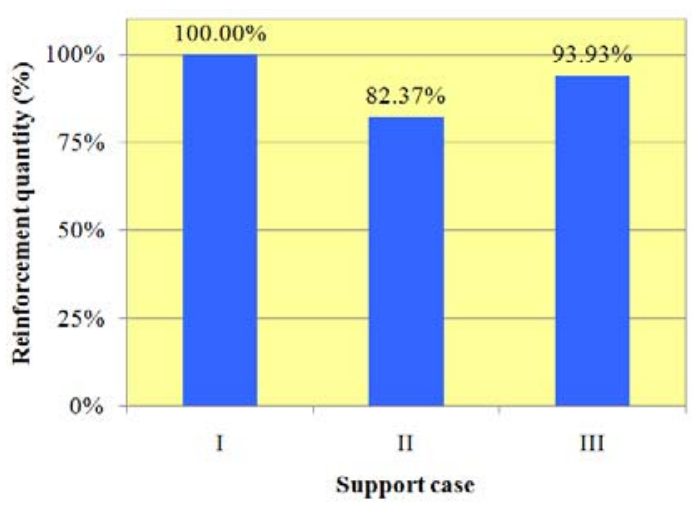

f)

Fig. 13 - Percentage differences d) raft reinforcement quantity e) pile reinforcement quantity f) total reinforcement quantity (raft + piles)

\subsection{Observations}

The charts show a large difference in settlement for the second model when compared to the other two. This phenomenon was expected, because the elastic supports are far from rigid (as in the other two models). On one hand, this model is more accurate than the fixed model, because 
the soil is not rigid. On the other hand, modern design codes specify fixed supports for piles embedded in rock, so the third model should be even more accurate.

Looking at this phenomenon from the other perspective, because the raft has a large settlement, the efforts that appear in the raft are smaller than the ones in the other two cases. Again, the effect was expected because the energy from the loads is transformed in larger settlements, rather than in efforts in the raft.

The same can be said for the piles as well, although in the case of the piles, the results of the first model (effort magnitude and diagram shapes) resemble more of a column model than a pile. In order to accurately model the soil-pile interaction a specialized design software should be used.

\section{Conclusions}

Due to the large settlement of the foundation (explained in the observations above) the efforts in the raft have a smaller value in the second design model. Because of this effect, the necessary reinforcement area for the raft is smaller too, the difference between this model and the first one being of almost $18 \%$ (22 tons), and 12\% (14 tons) with respect to the third.

The model considered in the design phase can have a considerable impact on the technical and economic parts of the project, both the lateral interaction between the piles and the soil (case 1 vs. $2 \& 3$ ) and the vertical interaction between the piles and the bedrock (case 2 vs. 3) affect the foundation structural response. In this case the reinforcement quantity, emphasized above, bought, shaped and placed in their position on the raft, translate into a loss of time and money for all parts involved in the project.

\section{References}

[1]. Gogu, M. (2011). Conversia Neconvențională a Energiei Electrice, Retrieved February 20, 2013, from http://www.mircea-gogu.ro/html/conversia neconventionala cuprins.html

[2]. ECOVOLT Romania - LP ELECTRIC Systems. (2010) Diagramă turbină eoliană. Retrieved February 22, 2013, from http://www.lpelectric.ro/ro/support/wind_diag_ro.html

[3]. Ilie, V. et al. (1984). Utilizarea energiei vântului. București, România: Editura Tehnică.

[4]. Manwell, J.F., McGowan J. G. \& Rogers A. L. (2009). Wind energy explained. Theory, design and application ( $2^{\text {nd }}$ edition). Chichester, United Kingdom: John Wyley \& Sons, Ltd.

[5]. Global Wind Energy Council. (2013). Global Wind Report. Retrieved March 2, 2013, from http://www.gwec.net/publications/global-wind-report-2/

[6]. The European Wind Energy Association. (2013). Wind in power. 2012 European statistics. Retrieved March 2, 2013, from http://www.ewea.org/

[7]. Burton T. et.al. (2011). Wind energy handbook ( $2^{\text {nd }}$ edition). Chichester, United Kingdom: John Wyley \& Sons, Ltd.

[8]. Fraunhofer Gesellschaft. (2010). Cost Efficiency. Investments Costs. Retrieved March 2, 2013, from http://windmonitor.iwes.fraunhofer.de/

[9]. Ministerul Dezvoltării Regionale și Turismului. (2011). Normativ privind proiectarea geotehnică a fundaţiilor pe piloți. NP 123: 2010. București, România. 